\title{
THE RELATIONSHIP BETWEEN WAIST CIRCUMFERENCE AND SYSTOLIC BLOOD PRESSURE
}

\author{
Miranti Dewi Pramaningtyas, Kaka Citta Prasiddha, Reza Ishak Estiko \\ Department of Physiology, Faculty of Medicine, Universitas Islam Indonesia, Yogyakarta, \\ Indonesia \\ Email miranti.dewi@uii.ac.id
}

\begin{abstract}
ABSTRAK
Pendahuluan: Lingkar pinggang yang melebihi normal menjadi salah satu tanda adanya obesitas sentral. Obesitas sentral menjadi faktor risiko peningkatan tekanan darah. Lingkar pinggang adalah indeks antropometri untuk obesitas sentral. Tujuan: Penelitian ini bertujuan mengetahui hubungan antara lingkar pinggang dan tekanan darah sistolik. Metode: Penelitian ini menggunakan metode cross-sectional dengan menghubungkan data tekanan darah sistolik dan lingkar pinggang. Hasil: Sebanyak 45 partisipan laki-laki dan perempuan memenuhi kriteria inklusi dalam penelitian ini. Rerata lingkar pinggang (cm) adalah 79,90 $\pm 1,55$, dan rerata tekanan darah sistolik ( $\mathrm{mmHg}$ ) adalah 107,29 \pm 1,64. Dari semua partisipan, 84,4\% memiliki tekanan darah sistolik normal, 13,3\% prehipertensi, 2,2\% hipertensi stadium 1. Untuk lingkar pinggang, sebanyak 21 dari 27 laki-laki masuk kategori obesitas sentral (77,8\%) lainnya memiliki lingkar pinggang normal (22,2\%). Pada subyek perempuan, sebanyak 6 dari 18 perempuan mengalami obesitas sentral (33,3\%), dan 12 perempuan memiliki lingkar pinggang normal (66,7\%). Hasil korelasi Spearman menunjukkan p=0,034. Kesimpulan: Penelitian menunjukkan bahwa ada hubungan antara lingkar pinggang dan tekanan darah sistolik yang bermakna.
\end{abstract}

Kata kunci: Tekanan darah sistolik, lingkar pinggang, obesitas sentral

\begin{abstract}
Introduction: Waist circumference that exceeds normal becomes one of the signs of central obesity. Central obesity is a risk factor of elevated blood pressure. Waist circumference is the anthropometric index for central obesity. Aim: This study aims to find out the relationship between waist circumference and systolic blood pressure. Method: This study used a cross-sectional method by correlate systolic blood pressure and waist circumference data. Results: A total of 45 male and female participants met the inclusion criteria in the study. The average waist circumference $(\mathrm{cm})$ is $79.90 \pm 1.55$, and the average systolic blood pressure $(\mathrm{mmHg})$ is $107.29 \pm 1.64$. Of all participants, $84.4 \%$ had normal systolic blood pressure, $13.3 \%$ prehypertension, $2.2 \%$ stage 1 hypertension. For waist circumference, 21 out of 27 men in the central obesity category (77.8\%) had a normal waist circumference (22.2\%). In female subjects, 6 out of 18 women were centrally obese (33.3\%), and 12 women had normal waist circumference (66.7\%). Spearman's correlation results show $p=0.034$. Conclusion: Research shows that there is a significant correlation between waist circumference and systolic blood pressure.
\end{abstract}

Keywords: Sistolic blood pressure, waist cisrcumference, central obesity 


\section{INTRODUCTION}

Blood pressure (BP) is one of the global health problems, including in Indonesia. Hypertension becomes a worldwide comorbid factor leading to 9.4 million deaths, and $7 \%$ of the burden of disease arises in Disability-Adjusted Life Years (DALYs). According to the Indonesian Basic Health Research (Riskesdas) of 2018, the prevalence of hypertension reached $34.1 \%$ nationwide with the highest prevalence in South Kalimantan province $(44.1 \%){ }^{1}$

Central obesity consists of subcutaneous fat and visceral fat centered in the stomach. When subcutaneous fat tissue is no longer able to store fat, fat will be stored in visceral fat tissue. In Indonesia, the prevalence of central obesity among the population aged 15 years and older was $26.6 \%$ in 2013, correspondingly higher than that in 2007 which was $18.8 \% .^{2}$ Fat in the abdomen, especially visceral fat, has a high lipolytic activity that may lead to metabolic and cardiovascular diseases as it raises $\mathrm{BP} .^{3}$

Studies show that overweight and increasing BP are correlated. The distribution of fat in the body becomes an important contributor to such correlation. ${ }^{2,4}$ Central obesity and increased BP are classified into metabolic syndrome, which includes insulin resistance and dyslipidemia. The accumulation of fat in the stomach significantly affects the relationship between BP and metabolic syndrome, and insulin resistance with hyperinsulinemia is thought to link central obesity and increasing BP. ${ }^{2,5}$ This hypothesis is also supported by frequent central obesity and increasing blood hyperinsulinemia, intolerance of glucose, as well as increasing gout and triglycerides. 5,6 However, the underlying mechanism, especially the role of central obesity, in influencing insulin resistance remains unclear.

One indicator to identify central obesity is the measurement of waist circumference (WC). ${ }^{7}$ Such measure is more accurate in predicting metabolic syndrome and cardiovascular disease compared to the measure of body mass index (BMI) and waist-to-hip ratio (WHR) because BMI is incompatible with the distribution of intraabdominal fat. According to WHO, the cutoff of central obesity among the population in South Asia, China, Japan, and Indonesia is $\geq 90 \mathrm{~cm}$ for male and $\geq 80 \mathrm{~cm}$ for female. ${ }^{4}$ This study aims to observe the correlation between WC and systolic BP of medical students in Universitas Islam Indonesia.

\section{METHODS}

This research was an analytical observational study with a cross-sectional design conducted at the physiology laboratory of the Faculty of Medicine, Universitas Islam Indonesia in September 2018. The samples consisted of medical students of Medical Faculty Universitas Islam Indonesia aged 18-22 years old selected using consecutive sampling and counted using the correlative

Table 1. Respondent characteristics

\begin{tabular}{cccc}
\hline Characteristic & Mean \pm SD & Minimum & Maximum \\
& & & \\
\hline Age (years) & $20.67 \pm 0.13$ & 18 & 22 \\
& & & \\
\hline WC (cm) & $79.90 \pm 1.55$ & 62 & 112 \\
\hline Systolic BP (mmHg) & $107.29 \pm 1.64$ & 80 & 140
\end{tabular}

Abbr: SD: standard deviation; WC: waist circumference; BP: blood pressure

research formula, yielding 45 samples.

The formula used to count minimum sample was as follow

$$
\begin{gathered}
N=\frac{(Z a+Z b)^{2}{ }^{2}}{0.5 \ln [(1+r) /(1-r)}+3 \\
N=\frac{(1,64+1,28)^{2}}{0.5 \ln [(1+0,45) /(1-0,45)}+3 \\
N=44,84 \\
N=\mathbf{4 5}
\end{gathered}
$$

The inclusion criteria were (1) academically active in faculty of medicine, (2) physically and mentally healthy, and (3) willing to take part in the research, while students having an illness or taking drugs that could affect blood pressure in the last one day were excluded. Systolic BP was measured twice using a sphygmomanometer and stethoscope with a rest interval of 5 minutes, and the average was then calculated. WC is declared central obesity if the result is $90 \mathrm{~cm}$ or more in males and $80 \mathrm{~cm}$ or more in females; otherwise, it is deemed normal. The research instruments used consisted of measuring tape, stethoscope, and sphygmomanometer, and the ethical clearance was obtained from the Medical and Health Research Ethics Committee of Medical Faculty Universitas Islam Indonesia with Number 1/Ka.Kom.Et/70/KE/X/2018 prior to the study. 
The data obtained was analyzed with a bivariate correlation analysis, particularly the Spearman correlation test, to find out the correlation between systolic BP and waist circumference. The results was significant when $\mathrm{p}<0.05$.

\section{RESULTS}

At the beginning of the study, the respondents consisting of 27 men $(60 \%)$ and 18 women (40\%) filled out an identity form and informed consent. Table 1 shows that the respondents are in the 18 to 22 age range. In adolescents, the risk of developing hypertension is much smaller than among the elderly. The average WC is $79.90 \pm 1.55$ with a minimum value of 62 and a maximum of $112 \mathrm{~cm}$ while the systolic BP $(\mathrm{mmHg})$ has an average of $107.29 \pm 1.64$ with 80 $\mathrm{mmHg}$ and $140 \mathrm{mmHg}$ as the minimum and maximum measurements, respectively. Of the 45 respondents, $38(84.4 \%)$ had normal systolic BP, 6 (13.3\%) had prehypertension, and 1 (2.2\%) had stage 1 hypertension.

This study used a bivariate correlation analysis, particularly the Spearman correlation test, due to the non-normal data distribution. Table 2 shows $\mathrm{p}<0.05$ with 0.034 significance value, thus indicating a significant relationship between WC and systolic BP. The obtained correlation coefficient is 0.316 which signifies a weak correlation, and since the direction results in a positive correlation, the greater the WC, the higher the systolic BP.

Table 2. Correlation between waist circumference and systolic blood pressure

\begin{tabular}{llll}
\hline Variable & Mean \pm SD & Correlation Coefficient & P value \\
\hline WC $(\mathbf{c m})$ & $79.90 \pm 1.55$ & 0.316 & 0.034 \\
\hline
\end{tabular}

Systolic BP $(\mathbf{m m H g}) \quad 107.29 \pm 1.64$

Notes: Correlation is significant at P value <0.05. Abbr: SD: standard deviation; WC: waist circumference; BP: blood pressure

\section{DISCUSSION}

In this study, the smallest WC in female respondents was $62 \mathrm{~cm}$ and the largest was $99 \mathrm{~cm}$, while the smallest WC in male respondents was 69 $\mathrm{cm}$ and the largest was $112 \mathrm{~cm}$. In males, $21(77.8 \%)$ respondents had normal WC, and $6(22.2 \%)$ had excess WC. In the findings, $12(66.7 \%)$ respondents had normal WC, while $6(33.3 \%)$ had excessive WC.

The results of this study are consistent with the results of the study of Poirier et.al. (2005) in 1844 people aged 18-74 years from the Quebec Health Survey with significant results $(\mathrm{p}<0.5)$ which means that there is a relationship between WC with a person's BP. ${ }^{8}$ This result is also supported by the study of Zhu et.al. and Dewi et.al. that showed correlation between WC and BP, both in men and women. ${ }^{9,10}$

Excessive intraabdominal fat, which is interpreted by the person's WC, results in central obesity. Central obesity is a metabolic syndrome, where its increase will cause various disorders in the body, one of which decreases the levels of adiponectin as an antiatherogenic which will increase blood pressure. ${ }^{11}$ Measuring WC using a measuring tape is the best anthropometry technique for determining fat deposits around the abdomen. The cause of increased WC is due to various factors, including lifestyle, improper diet, lack of activity, and excessive consumption of energy needed. These factors cause an imbalance of the stored energy and the energy used. Besides genetic factors also influence the incidence of obesity. ${ }^{12}$.
People with central obesity will have higher body mass index (BMI) in common, including younger age. Waist circumference also associated with elevated BP in children with normal BMI. ${ }^{13}$ It is important to observe waist circumference in children to avoid metabolic disease in the next periode of age. ${ }^{14}$ Elevated BP will increases the total peripheral resistance, which is caused by the accumulation of visceral fat, and stiffness of the large arteries. Therefore, an increase in systolic BP affects the risk of cardiovascular disease. ${ }^{15}$

One of the predictive factor for elevated systolic blood pressure is waist circumference. ${ }^{16}$ Waist circumference is also associated in hypertension incident. ${ }^{17}$ Setyanda (2015) said that people who have a high WC measure are more at risk of developing hypertension, although WC does not directly affect the occurrence of hypertension. The greater the WC, the greater fat deposits in the abdominal area, especially visceral fat which will increase the activity of lipolysis and lipogenesis, thereby increasing free fatty acids in the blood which will later affect physiological processes in the body. $^{12}$

\section{CONCLUSION}

There is a relationship between WC and systolic BP with a weak correlation value. Therefore, prevention of central obesity is required to avoid increased blood pressure. This study has its limitations, including the small number of samples which makes it unable to represent the overall youth population aged 18-22 years. Further research is 
therefore needed with a larger sample size to describe youth population in general.

\section{ACKNOWLEDGMENT}

The abstract part has been presented at the Hypertension Seoul 2018 conference.

\section{DISCLOSURE}

The authors thank to Faculty of Medicine Universitas Islam Indonesia for funding this research

\section{REFERENCES}

1. Kemenkes RI. Hasil Riset Kesehatan Dasar Tahun 2018. Kementrian Kesehat RI. 2018;53(9):1689-99.

2. Litbang Kemkes. Riset Kesehatan Dasar (RISKESDAS) 2013. Lap Nas 2013. 2013;

3. Din-Dzietham R, Liu Y, Bielo MV, Shamsa F. High blood pressure trends in children and adolescents in national surveys, 1963 to 2002 . Circulation. 2007;116(13):1488-96.

4. Kastorini CM, Milionis HJ, Ioannidi A, Kalantzi K, Nikolaou V, Vemmos KN, et al. Adherence to the Mediterranean diet in relation to acute coronary syndrome or stroke nonfatal events: A comparative analysis of a case/case-control study. Am Heart J. 2011;162(4):717-24.

5. Midha T. Cut-off of body mass index and waist circumference to predict hypertension in Indian adults. World J Clin Cases. 2014;2(7):272.

6. Klop B, Elte JWF, Cabezas MC. Dyslipidemia in Obesity: Mechanisms and Potential Targets. Nutrients. 2013;5(4):1218-40.

7. World Health Organisation (WHO). WHO Waist Circumference and Waist-Hip Ratio. Report of a WHO Expert Consultation. Geneva, 8-11 December 2008. 2008;(December):8-11.

8. Poirier P, Lemieux I, Mauriège $\mathrm{P}$, Dewailly $\mathrm{E}$, Blanchet $\mathrm{C}$, Bergeron J, et al. Impact of waist circumference on the relationship between blood pressure and insulin: The Quebec health survey. Hypertension. 2005;45(3):363-7.
9. Zhu SK, Wang ZM, Heshka S, Heo M, Faith MS, Heymsfield SB. Waist circumference and obesity-associated risk factors among whites in the third National Health and Nutrition Examination Survey: Clinical action thresholds. Am J Clin Nutr. 2002;76(4):743-9.

10. Dewi SC, Furqon M, Danial D. the Relationship of the Body Mass Index and Waist Circumference With Blood Pressure At Karang Asam Public Health Center Samarinda. J Ilmu Kesehat. 2020;7(2):10310.

11. Gotera W, Suastika K, Santoso A, Kuswardhani T. Hubungan Antara Obesitas Sentral Dengan Adiponektin Pada Pasien Geritari Dengan Penyakit Jantung Koroner. J Intern Med. 2006;7(2).

12. Setyanda YOG, Sulastri D, Lestari Y. Hubungan Merokok dengan Kejadian Hipertensi pada Laki-Laki Usia 35-65 Tahun di Kota Padang. J Kesehat Andalas. 2015;4(2):434-40.

13. Pazin DC, Rosaneli CF, Olandoski M, de Oliveira ERN, Baena CP, Figueredo AS, et al. Waist circumference is associated with blood pressure in children with normal body mass index: A cross-sectional analysis of 3,417 school children. Arq Bras Cardiol. 2017;109(6):509-15.

14. Chou YC, Choy CS, Liao CC. Hip Circumference and Risk of Elevated Blood Pressure in Children: A Cross-Sectional Study. J Arrhythmia. 2011;27.

15. Sun Z. Aging, arterial stiffness, and hypertension. Hypertension. 2015;65(2):252-6.

16. Dewi R, Ramayati R, Rosdiana N, Ramayani OR, Siregar R, Siregar B. Waist circumference, body mass index, and skinfold thickness as potential risk factors for high blood pressure in adolescents. Paediatr Indones. 2019;59(2):79-86.

17. Momin M, Fan F, Li J, Jia J, Zhang L, Zhang Y, et al. Joint Effects of Body Mass Index and Waist Circumference on the Incidence of Hypertension in a Community-Based Chinese Population. Obes Facts. 2020;13(2):245-55. 